\title{
The Role of Composition and Phase upon the Lattice Nitrogen Reactivity of Ternary Molybdenum Nitrides
}

\author{
Angela Daisley $^{1} \cdot$ Lucy Costley-Wood $^{1} \cdot$ Justin S. J. Hargreaves ${ }^{1}$ (i)
}

Accepted: 24 March 2021 / Published online: 27 April 2021

(c) The Author(s) 2021

\begin{abstract}
The reactivity of the lattice nitrogen in the filled $\beta-\mathrm{Mn}$ structured $\mathrm{Co}_{2} \mathrm{Mo}_{3} \mathrm{~N}$ and the $\eta$-carbide structured $\mathrm{Co}_{3} \mathrm{Mo}_{3} \mathrm{~N}$ and $\mathrm{Fe}_{3} \mathrm{Mo}_{3} \mathrm{~N}$ has been investigated under 3:1 $\mathrm{H}_{2} / \mathrm{Ar}$ at temperatures up to $900{ }^{\circ} \mathrm{C}$. The lattice nitrogen in $\mathrm{Co}_{3} \mathrm{Mo}_{3} \mathrm{~N}$ was found to be reactive, as reported previously, whereas $\mathrm{Co}_{2} \mathrm{Mo}_{3} \mathrm{~N}$ was shown to be stable up to $800{ }^{\circ} \mathrm{C}$. Upon $\mathrm{H}_{2} / \mathrm{Ar}$ treatment at $900{ }^{\circ} \mathrm{C}$, the $\mathrm{Co}_{2} \mathrm{Mo}_{3} \mathrm{~N}, \mathrm{Co}_{3} \mathrm{Mo}_{3} \mathrm{~N}$ and $\mathrm{Fe}_{3} \mathrm{Mo}_{3} \mathrm{~N}$ phases decomposed. These results suggest that both metal composition and phase have an influence on the bulk lattice nitrogen reactivity of the ternary nitrides.
\end{abstract}

Keywords Ammonia $\cdot$ Cobalt $\cdot$ Iron $\cdot$ Molybdenum $\cdot$ Nitride

\section{Introduction}

Ammonia production is of high importance as it can be used as a precursor to form synthetic fertilisers. The industrial route for producing ammonia is via the Haber-Bosch process and this is stated to sustain around $40 \%$ of the world population [1]. However, when considering the entirety of the process, including the feedstream production, it accounts for $1-2 \%$ of the world energy demand [2]. One possible way to overcome this disadvantage is the development of a process that could operate under more moderate conditions and facilitate localised and sustainable production. However, this would require the development of a more active ammonia synthesis catalyst. The $\eta$-carbide structured $\mathrm{Co}_{3} \mathrm{Mo}_{3} \mathrm{~N}$ has a high ammonia synthesis activity, especially when doped with a low percentage of $\mathrm{Cs}^{+}$and is reported to have a higher rate than the iron-based catalyst used in the Haber Bosch process [2]. One possible explanation for the high activity of this nitride has been proposed by a volcano relationship, where the combination of $\mathrm{Co}$ and Mo gives a material with an almost optimal nitrogen binding energy and results in a high turnover frequency for ammonia synthesis [3]. In this

Angela Daisley

angela.daisley@glasgow.ac.uk

Justin S. J. Hargreaves

Justin.Hargreaves@glasgow.ac.uk

1 School of Chemistry, Joseph Black Building, University of Glasgow, Glasgow G12 8QQ, UK proposal, the lattice nitrogen is suggested to have no active role and CoMo is the active phase. The role of the lattice nitrogen is stated to be to ensure that the correct structural ordering occurs such that the (111) face containing both $\mathrm{Co}$ and Mo is exposed. One alternative explanation for the activity of $\mathrm{Co}_{3} \mathrm{Mo}_{3} \mathrm{~N}$ is that it proceeds via a Mars-van Krevelen mechanism and hence, the lattice nitrogen is reactive. In this mechanism, the lattice nitrogen is directly hydrogenated to yield ammonia, generating a transient lattice vacancy, which is then replenished by gas-phase nitrogen. This proposed explanation has been supported by experimental work, where an investigation into the isostructural $\mathrm{Co}_{3} \mathrm{Mo}_{3} \mathrm{C}$ phase showed that the carbide required a higher temperature than $\mathrm{Co}_{3} \mathrm{Mo}_{3} \mathrm{~N}$ before activity was exhibited and nitridation of the lattice carbon occurred during the reaction [4]. Furthermore, nitrogen isotopic exchange studies have shown that a substantial percentage of the lattice nitrogen in $\mathrm{Co}_{3} \mathrm{Mo}_{3} \mathrm{~N}$ can be exchanged, depending on the pre-treatment conditions used [5]. In addition, computational modelling studies have suggested that an associative $\mathrm{N}_{2}$ activation pathway on $\mathrm{Co}_{3} \mathrm{Mo}_{3} \mathrm{~N}$ may occur at nitrogen lattice vacancies [6] and that there are significant lattice nitrogen vacancies for this nitride at temperatures relevant for ammonia synthesis [7]. This mechanism differs significantly from the widely proposed view of dinitrogen dissociation being the rate determining step in relation to promoted iron-based ammonia synthesis catalysts, although for that system Spencer has pointed out that under industrially relevant conditions ammonia synthesis cannot be described in terms of a single 
rate determining step and that hydrogenation of adsorbed nitrogen species and ammonia desorption play a more significant role [8].

Related to the reactivity of lattice $\mathrm{N}, \mathrm{Co}_{3} \mathrm{Mo}_{3} \mathrm{~N}$ is also of interest due to its ability to lose half of its lattice nitrogen to form $\mathrm{Co}_{6} \mathrm{Mo}_{6} \mathrm{~N}$, where the remaining lattice nitrogen relocates from the $16 \mathrm{c}$ Wyckoff site to the $8 \mathrm{a}$ site $[9,10]$. The original nitride can then be regenerated from $\mathrm{Co}_{6} \mathrm{Mo}_{6} \mathrm{~N}$ under either $\mathrm{N}_{2} / \mathrm{H}_{2}$ or pure $\mathrm{N}_{2}[9,11]$. Therefore, the lattice nitrogen in $\mathrm{Co}_{3} \mathrm{Mo}_{3} \mathrm{~N}$ has been shown to be highly reactive. This is not the case for the filled $\beta-\mathrm{Mn}$ structured $\mathrm{Ni}_{2} \mathrm{Mo}_{3} \mathrm{~N}$, where the bulk lattice nitrogen has been shown to be unreactive, even at temperatures of $900{ }^{\circ} \mathrm{C}$ under $3: 1 \mathrm{H}_{2} / \operatorname{Ar}$ [12]. Furthermore, the loss of lattice nitrogen from the $\eta$-carbide structured $\mathrm{Fe}_{3} \mathrm{Mo}_{3} \mathrm{~N}$ has been reported to be minimal under $3: 1 \mathrm{H}_{2} /$ Ar up to $800{ }^{\circ} \mathrm{C}[14,15]$. A comparison with the $\eta$-carbide structured $\mathrm{Ni}_{3} \mathrm{Mo}_{3} \mathrm{~N}$, which is isostructural with both $\mathrm{Co}_{3} \mathrm{Mo}_{3} \mathrm{~N}$ and $\mathrm{Fe}_{3} \mathrm{Mo}_{3} \mathrm{~N}$, would be of further interest. However, this phase has not yet been successfully prepared even though, as documented elsewhere, there have been incorrect reports of its existence published in the literature [15]. Nitridation of a $\mathrm{NiMoO}_{4}$ precursor, $\mathrm{Ni}_{3} \mathrm{Mo}_{3} \mathrm{C}$ or $\mathrm{Ni}_{6} \mathrm{Mo}_{6} \mathrm{C}$ instead yields a mixture of $\mathrm{Ni}$ metal and $\mathrm{Ni}_{2} \mathrm{Mo}_{3} \mathrm{~N}$ $[12,13]$. The filled $\beta$-Mn structured $\mathrm{Co}_{2} \mathrm{Mo}_{3} \mathrm{~N}$ is a known phase and Adamski et al. have reduced a mixture containing both $\mathrm{Co}_{2} \mathrm{Mo}_{3} \mathrm{~N}$ and $\mathrm{Co}_{3} \mathrm{Mo}_{3} \mathrm{~N}$ phases under pure hydrogen at $700{ }^{\circ} \mathrm{C} . \mathrm{Co}_{3} \mathrm{Mo}_{3} \mathrm{~N}$ was observed to have transformed to $\mathrm{Co}_{6} \mathrm{Mo}_{6} \mathrm{~N}$, as would be expected for this phase $[9,10]$ and the lattice nitrogen in $\mathrm{Co}_{2} \mathrm{Mo}_{3} \mathrm{~N}$ appeared to be less reactive under these conditions.

The basis of the current study is to establish the potential role and structure/composition activity dependence of lattice nitrogen reactivity in terms of ternary metal nitrides. The analysis of the lattice nitrogen reactivity of nitrides through the comparison of their ammonia synthesis rates under $\mathrm{Ar} /$ $\mathrm{H}_{2}$ would give an insight into the structure-activity and composition-activity relationships. Therefore, an investigation of the $\eta$-carbide structured $\mathrm{Fe}_{3} \mathrm{Mo}_{3} \mathrm{~N}$ has been performed to provide a comparison with the isostructural $\mathrm{Co}_{3} \mathrm{Mo}_{3} \mathrm{~N}$. This information will give an insight into the role metal composition has on the lattice nitrogen reactivity and it is hoped that a more thorough understanding of this aspect may be applied to the further development of novel ammonia synthesis catalysts.

\section{Experimental}

\subsection{Preparation of $\mathrm{Fe}_{3} \mathrm{Mo}_{3} \mathrm{~N}$}

Iron molybdenum oxide was prepared by a similar procedure as detailed by Bem et al. [17]. 0.25 $\mathrm{M}$ aqueous solution of $37.1 \mathrm{~mL}$ of iron (II) chloride tetrahydrate $\left(\mathrm{FeCl}_{2} \cdot 4 \mathrm{H}_{2} \mathrm{O}\right.$,
Sigma Aldrich, ReagentPlus, 98\%) was added dropwise to $0.66 \mathrm{M}$ aqueous solution of $14 \mathrm{~mL}$ of sodium molybdate dihydrate $\left(\mathrm{Na}_{2} \mathrm{MoO}_{4} \cdot 2 \mathrm{H}_{2} \mathrm{O}\right.$, Hopkin and Williams, Analar, 99.0-102.0\%). The solid product formed instantly upon the mixing of the two solutions. The mixture was left to stir for $1 \mathrm{~h}$ once all the $\mathrm{FeCl}_{2} \cdot 4 \mathrm{H}_{2} \mathrm{O}$ aqueous solution was added. The solid was obtained by vacuum filtration and was washed twice with distilled water and once with ethanol. The oxide powder was dried overnight in an oven at $150{ }^{\circ} \mathrm{C}$ and was then calcined under $60 \mathrm{~mL} / \mathrm{min}$ of nitrogen at $500{ }^{\circ} \mathrm{C}$ for $6 \mathrm{~h}$. Finally, the oxide was cooled down to room temperature under nitrogen.

$\mathrm{Fe}_{3} \mathrm{Mo}_{3} \mathrm{~N}$ was prepared by ammonolysis of the oxide precursor under $94 \mathrm{~mL} / \mathrm{min} \mathrm{NH}_{3}$ gas (BOC 99.98\%). The temperature was increased from room temperature to $357^{\circ} \mathrm{C}$ at a ramp rate of $5.6{ }^{\circ} \mathrm{C} / \mathrm{min}$, then to $447{ }^{\circ} \mathrm{C}$ at a ramp rate of $0.2^{\circ} \mathrm{C} / \mathrm{min}$ and a final increase of $2.1^{\circ} \mathrm{C} / \mathrm{min}$ to $785^{\circ} \mathrm{C}$, then held at this temperature for $5 \mathrm{~h}$ before being cooled to room temperature. The system was flushed with nitrogen for $30 \mathrm{~min}$ and then the resultant material was passivated under a mixture of $2 \% \mathrm{O}_{2} / \mathrm{Ar}$ and $\mathrm{N}_{2}$ for $1 \mathrm{~h}$.

\subsection{Preparation of $\mathrm{Co}_{2} \mathrm{Mo}_{3} \mathrm{~N}$}

Cobalt molybdenum oxide was prepared by using a modified form of the Pechini method as described by Bion et al. [18]. The necessary amounts of ammonium molybdate tetrahydrate $\left(\left(\mathrm{NH}_{4}\right)_{6} \mathrm{Mo}_{7} \mathrm{O}_{24} \cdot 4 \mathrm{H}_{2} \mathrm{O}\right.$, Fluka Analytical, puriss. p.a., ACS reagent, $\geq 99.0 \%$ ) and cobalt (II) nitrate hexahydrate $\left(\mathrm{Co}\left(\mathrm{NO}_{3}\right)_{2} \cdot 6 \mathrm{H}_{2} \mathrm{O}\right.$, Alfa Aesar, ACS, 98.0-102.0\%, crystalline) were added to a $10 \%$ aqueous solution of nitric acid to give a 2:3 ratio of Co:Mo. Citric acid monohydrate $\left(\mathrm{C}_{6} \mathrm{H}_{8} \mathrm{O}_{7}\right.$. $\mathrm{H}_{2} \mathrm{O}$, Sigma Aldrich, ACS reagent, $\geq 99.0 \%$ ) was then added to the mixture. The mixture was stirred at room temperature, until the starting materials had been dissolved. Subsequently, the mixture was evaporated off at $70^{\circ} \mathrm{C}$, until a red coloured gel had formed. The gel was dried in an oven overnight at $120^{\circ} \mathrm{C}$ and was then calcined in air at $500{ }^{\circ} \mathrm{C}$ for $2 \mathrm{~h}$.

$\mathrm{Co}_{2} \mathrm{Mo}_{3} \mathrm{~N}$ was prepared via nitridation of the mixed oxide precursor under $3: 1 \mathrm{H}_{2} / \mathrm{N}_{2}$ gas mixture at $700{ }^{\circ} \mathrm{C}$ for $3 \mathrm{~h}$ with a flow rate of $60 \mathrm{~mL} / \mathrm{min}$. A heating ramp rate of $10{ }^{\circ} \mathrm{C} / \mathrm{min}$ was used to reach $700{ }^{\circ} \mathrm{C}$.

\subsection{Preparation of $\mathrm{Co}_{3} \mathrm{Mo}_{3} \mathrm{~N}$}

Cobalt molybdenum oxide $\left(\mathrm{CoMoO}_{4}\right)$ was prepared by the reaction of the necessary amounts of ammonium molybdate tetrahydrate $\left(\left(\mathrm{NH}_{4}\right)_{6} \mathrm{Mo}_{7} \mathrm{O}_{24} \cdot 4 \mathrm{H}_{2} \mathrm{O}, 99.98 \%\right.$, SigmaAldrich) with cobalt (II) nitrate hexahydrate $\left(\mathrm{Co}\left(\mathrm{NO}_{3}\right)_{2} \cdot 6 \mathrm{H}_{2} \mathrm{O},>98 \%\right.$, Sigma-Aldrich). The starting materials were dissolved separately in either $100 \mathrm{~mL}$ or $150 \mathrm{~mL}$ of deionised water, respectively. The solution of cobalt was then added dropwise to the molybdenum 
solution. The resultant mixture was heated to $80{ }^{\circ} \mathrm{C}$ until a purple solid had formed, then vacuum filtered and the purple precipitate was washed twice with deionised water and once with ethanol. The oxide powder $\left(\mathrm{CoMoO}_{4} \cdot \mathrm{nH}_{2} \mathrm{O}\right)$ was dried overnight in an oven at $150{ }^{\circ} \mathrm{C}$ and was then calcined in air at $600{ }^{\circ} \mathrm{C}$ for $3 \mathrm{~h}$.

$\mathrm{Co}_{3} \mathrm{Mo}_{3} \mathrm{~N}$ was prepared by nitridation of the oxide precursor under 3:1 $\mathrm{H}_{2} / \mathrm{N}_{2}$ gas mixture (BOC, 99.98\%) at either $700{ }^{\circ} \mathrm{C}, 800{ }^{\circ} \mathrm{C}$ or $900{ }^{\circ} \mathrm{C}$ for $4 \mathrm{~h}$ with a flow rate of $60 \mathrm{~mL} / \mathrm{min}$. A heating ramp rate of $10{ }^{\circ} \mathrm{C} / \mathrm{min}$ was used. The resultant nitride was cooled to ambient temperature under 3:1 $\mathrm{H}_{2} / \mathrm{N}_{2}$. For clarity, the nitride prepared at the different temperatures will be referred to as either CoMoN700, CoMoN800 and $\mathrm{Co}_{3} \mathrm{Mo}_{3} \mathrm{~N} 900$.

\subsection{Lattice Nitrogen Reactivity Testing}

Approximately $0.3 \mathrm{~g}$ of material was tested at ambient pressure under 3:1 $\mathrm{H}_{2} / \mathrm{Ar}$ (BOC, 99.98\%) with a gas flow rate of $60 \mathrm{~mL} / \mathrm{min}$. The stability and possible lattice nitrogen reactivity of the prepared $\mathrm{Co}_{2} \mathrm{Mo}_{3} \mathrm{~N}$ and $\mathrm{Co}_{3} \mathrm{Mo}_{3} \mathrm{~N}$ material was investigated by testing the material under $3: 1$ $\mathrm{H}_{2} / \mathrm{Ar}$ at $700{ }^{\circ} \mathrm{C}, 800{ }^{\circ} \mathrm{C}$ and $900{ }^{\circ} \mathrm{C} . \mathrm{Fe}_{3} \mathrm{Mo}_{3} \mathrm{~N}$ was also examined at $900{ }^{\circ} \mathrm{C}$ under $3: 1 \mathrm{H}_{2} / \mathrm{Ar}$ for its lattice nitrogen reactivity. The decrease in conductivity of a $0.00108 \mathrm{M}$ $200 \mathrm{~mL}$ solution of $\mathrm{H}_{2} \mathrm{SO}_{4}$, which the exit stream of gas flowed through, was used to determine the production of ammonia. At such high reaction temperatures $\left(700-900{ }^{\circ} \mathrm{C}\right)$, ammonia is thermodynamically unstable with respect to decomposition into $\mathrm{N}_{2}$ and $\mathrm{H}_{2}$.

\subsection{Material Characterisation}

Powder XRD patterns were obtained for the materials pre- and post-reaction by using a PANalytical X-Pert Pro Diffractometer $(40 \mathrm{kV}, 40 \mathrm{~mA})$ with a monochromatised $\mathrm{CuK} \alpha$ source $(1.5418 \AA \AA)$. The data was collected in the range of $5-85^{\circ} 2 \theta$ with a total scan time of $51 \mathrm{~min}$ and a step size of $0.02^{\circ}$. Phases were identified by comparison with the JCPDS database. CHN analysis was undertaken by combustion using an Exeter Analytical Inc CE-440 elemental analyser. SEM images were taken by using a Philips XL30 environmental scanning electron microscope. The samples were first covered with a film of gold/ palladium to reduce charging. The microscope was also used to acquire Energy-Dispersive X-ray spectroscopy (EDX). The BET surface area of the pre-reaction $\mathrm{Fe}_{3} \mathrm{Mo}_{3} \mathrm{~N}$ was measured using $\mathrm{N}_{2}$ physisorption undertaken using a Quantachrome Quadrasorb evo Gas Sorption Surface Area and Pore Size Analyzer. Approximately $0.1 \mathrm{~g}$ of the material was degassed at $110{ }^{\circ} \mathrm{C}$ overnight under vacuum before the measurement.

\section{Results and Discussion}

\subsection{Lattice Nitrogen Reactivity of $\mathrm{Fe}_{3} \mathrm{Mo}_{3} \mathrm{~N}$}

As the $\eta$-carbide structured $\mathrm{Co}_{3} \mathrm{Mo}_{3} \mathrm{~N}$ and filled $\beta$-Mn structured $\mathrm{Ni}_{2} \mathrm{Mo}_{3} \mathrm{~N}$ have been shown to have different lattice nitrogen reactivities, it would be of interest to investigate whether the phase or metal composition has the larger impact on the reactivity. This could lead to the development and design of active nitrides for ammonia synthesis. Therefore, the lattice nitrogen reactivity of another $\eta$-carbide structured nitride, $\mathrm{Fe}_{3} \mathrm{Mo}_{3} \mathrm{~N}$, has been investigated in this work. As this nitride has the same crystal structure type as $\mathrm{Co}_{3} \mathrm{Mo}_{3} \mathrm{~N}$ but a different metal composition, it may prove possible to gain an insight into the role of the metal composition-activity relationship. It has previously been reported that the lattice nitrogen of $\mathrm{Fe}_{3} \mathrm{Mo}_{3} \mathrm{~N}$ is less reactive than in $\mathrm{Co}_{3} \mathrm{Mo}_{3} \mathrm{~N}$. $\mathrm{Fe}_{3} \mathrm{Mo}_{3} \mathrm{~N}$ has been observed to be stable under $3: 1 \mathrm{H}_{2} / \mathrm{Ar}$ up to $800^{\circ} \mathrm{C}$, with a minimal loss of lattice nitrogen $[13,14]$. Furthermore, neutron diffraction analysis revealed that bulk nitrogen was not lost from $\mathrm{Fe}_{3} \mathrm{Mo}_{3} \mathrm{~N}$ [14]. A higher temperature has been investigated in the present study to investigate whether the bulk lattice nitrogen in the $\mathrm{Fe}_{3} \mathrm{Mo}_{3} \mathrm{~N}$ phase is reactive but requires a higher temperature than that observed for $\mathrm{Co}_{3} \mathrm{Mo}_{3} \mathrm{~N}$. The $\mathrm{Fe}_{3} \mathrm{Mo}_{3} \mathrm{~N}$ appeared from XRD to be phase pure when prepared from ammonolysis of an iron molybdenum oxide precursor as evidenced in Fig. 1a. The nitrogen analysis (Table 1) showed that the nitride had a considerably higher nitrogen content than the calculated stoichiometric value for $\mathrm{Fe}_{3} \mathrm{Mo}_{3} \mathrm{~N}(2.98 \mathrm{wt} \%)$. However, $\mathrm{NH}_{\mathrm{x}}$ species on the surface of the material, that

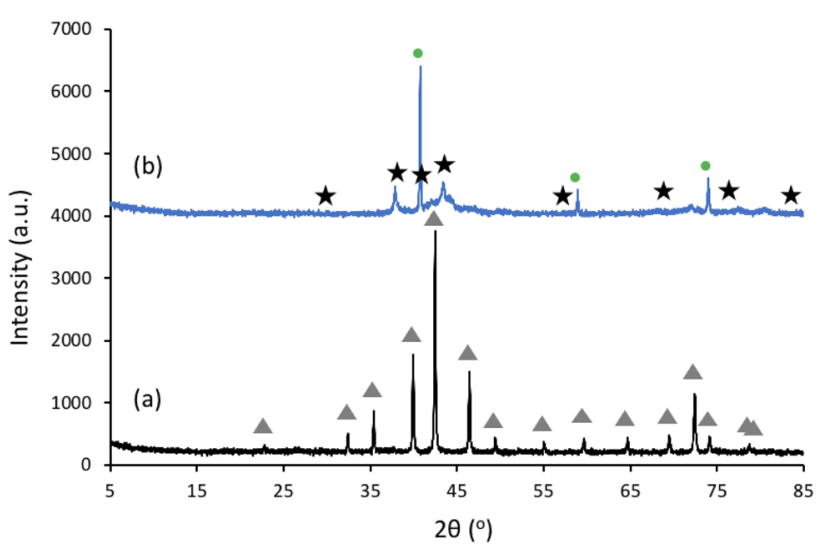

Fig. 1 XRD patterns of $\mathrm{Fe}_{3} \mathrm{Mo}_{3} \mathrm{~N}$ : a pre-reaction and $\mathbf{b}$ post-reaction with 3:1 $\mathrm{H}_{2} / \mathrm{Ar}$ at $900{ }^{\circ} \mathrm{C}$. ( $\triangle \mathrm{Fe}_{3} \mathrm{Mo}_{3} \mathrm{~N}$ (PDF ref.: 00-048-1408), (๖) Mo (PDF ref.: 01-089-5023) and ( $\star$ $) \varepsilon-\mathrm{Fe}_{3} \mathrm{~N}$ (PDF ref.: 01-073-2101) 
Table 1 Nitrogen analysis pre- and post-reaction for $\mathrm{Fe}_{3} \mathrm{Mo}_{3} \mathrm{~N}$

\begin{tabular}{ll}
\hline Material & Nitrogen content (wt\%) \\
\hline $\mathrm{Fe}_{3} \mathrm{Mo}_{3} \mathrm{~N}$ & 4.27 \\
$\mathrm{Fe}_{3} \mathrm{Mo}_{3} \mathrm{~N}$ post $\mathrm{H}_{2} / \mathrm{Ar} 900{ }^{\circ} \mathrm{C}$ & 0.49 \\
\hline
\end{tabular}

are a result of the preparation method, could account for this difference in values as could the presence of an amorphous $\mathrm{N}$ containing component. Representative SEM images show that $\mathrm{Fe}_{3} \mathrm{Mo}_{3} \mathrm{~N}$ consisted of rounded particles (Fig. 2). The material was observed to have a surface area of $13 \mathrm{~m}^{2} / \mathrm{g}$, which is comparable with those reported in the literature for this nitride [19, 20]. However, as the nitride was passivated prior to exposure to air, as is standard for nitride materials, the BET surface area will possibly not be representative of the area under the testing conditions. As expected, passivation of nitrides changes surface composition [21] and can lead to changes in surface area [22].

The reactivity of the lattice nitrogen in $\mathrm{Fe}_{3} \mathrm{Mo}_{3} \mathrm{~N}$ was examined by treating the nitride at $900{ }^{\circ} \mathrm{C}$ under $3: 1 \mathrm{H}_{2} / \mathrm{Ar}$ at ambient pressure for $7 \mathrm{~h}$. If the material operated via a Marsvan Krevelen mechanism for ammonia synthesis, a reduction in the nitrogen content might occur and additionally, there may be a transformation of the structure as was observed for the $\mathrm{Co}_{3} \mathrm{Mo}_{3} \mathrm{~N}$ counterpart. The conductivity profile (Online Resource Fig. S1) implies that only a minimal amount of ammonia was produced under these conditions. A total of $35 \mu \mathrm{mol}$ of ammonia was produced over the $7 \mathrm{~h}$ of the reaction. However, it must be noted that ammonia is thermodynamically unstable at this temperature and will decompose [23] and, therefore, the loss of lattice nitrogen in the final form of $\mathrm{N}_{2}$ will be more favourable. The post-reaction XRD pattern shows that the nitride had decomposed to Mo metal and an iron nitride phase under these reaction conditions (Fig. 1b). It appears that trace amounts of $\mathrm{Fe}_{3} \mathrm{Mo}_{3} \mathrm{~N}$ were still present in the material as reflections were observed at $42^{\circ}$ and $72^{\circ} 2 \theta$. The nitrogen analysis confirms the loss of lattice nitrogen from this material as there was a significant decrease post-reaction (Table 1). The percentage of the overall nitrogen that was removed from $\mathrm{Fe}_{3} \mathrm{Mo}_{3} \mathrm{~N}$ and was converted to ammonia was ca. $6 \%$, with the rest of the nitrogen presumably being lost in the form of $\mathrm{N}_{2}$. SEM analysis showed that the morphology was retained after the decomposition of the material compared to pre-reaction (Fig. 2).

The lattice nitrogen in $\mathrm{Fe}_{3} \mathrm{Mo}_{3} \mathrm{~N}$ was much more reactive at $900{ }^{\circ} \mathrm{C}$ than for the filled $\beta-\mathrm{Mn}$ structured $\mathrm{Ni}_{2} \mathrm{Mo}_{3} \mathrm{~N}$, which was shown to be stable at this temperature [12]. Therefore, this possibly suggests that metal composition has a major impact on the activity.

\subsection{Lattice Nitrogen Reactivity of $\mathrm{Co}_{2} \mathrm{Mo}_{3} \mathrm{~N}$}

The ability of the $\mathrm{Co}_{3} \mathrm{Mo}_{3} \mathrm{~N}$ phase to lose bulk lattice nitrogen at $700{ }^{\circ} \mathrm{C}$ under $\mathrm{H}_{2} / \mathrm{Ar}$ [24], contrasted with $\mathrm{Fe}_{3} \mathrm{Mo}_{3} \mathrm{~N}$ as discussed above, suggests that this is possibly due to the CoMo composition. Therefore, it was of interest to examine the filled $\beta$-Mn structured $\mathrm{Co}_{2} \mathrm{Mo}_{3} \mathrm{~N}$ phase, which has the same metal composition but different crystal structure type. Comparing the lattice nitrogen reactivity of $\mathrm{Co}_{2} \mathrm{Mo}_{3} \mathrm{~N}$ with the $\eta$-carbide structured $\mathrm{Co}_{3} \mathrm{Mo}_{3} \mathrm{~N}$ might provide an insight into the crystal structure-activity relationship. To investigate this potential relationship, attempts were made to prepare the pure phase $\mathrm{Co}_{2} \mathrm{Mo}_{3} \mathrm{~N}$. The modified Pechini method was chosen for the synthesis process as it has previously been used to synthesis pure phase filled $\beta-\mathrm{Mn}$ structured $\mathrm{Ni}_{2} \mathrm{Mo}_{3} \mathrm{~N}$ [18]. The filled $\beta$-Mn structured $\mathrm{Co}_{2} \mathrm{Mo}_{3} \mathrm{~N}$ was prepared via nitridation of the oxide precursor at $700{ }^{\circ} \mathrm{C}$ for three hours under $3: 1 \mathrm{H}_{2} / \mathrm{N}_{2}$. This was found to be the optimum preparation temperature and duration to give the highest amount of the desired nitride. The preparation of the pure phase nitride was unsuccessful, with instead a mixture of $\mathrm{Co}_{2} \mathrm{Mo}_{3} \mathrm{~N}, \mathrm{Co}_{3} \mathrm{Mo}_{3} \mathrm{~N}$ and $\beta-\mathrm{Mo}_{2} \mathrm{~N}_{0.78}$ being formed (Fig. 3). This material contained $3.82 \mathrm{wt} \%$ nitrogen from elemental analysis as presented in Table 2 (the expected stoichiometric nitrogen content of $\mathrm{Co}_{2} \mathrm{Mo}_{3} \mathrm{~N}$ is $3.34 \mathrm{wt} \%$ ). The SEM images of the mixed $\mathrm{Co}_{2} \mathrm{Mo}_{3} \mathrm{~N}$ show that the material had a porous and smooth surface (Fig. 4a). Although the material
Fig. 2 Representative SEM images of $\mathrm{Fe}_{3} \mathrm{Mo}_{3} \mathrm{~N}$ : a prereaction and b post $\mathrm{H}_{2} / \mathrm{Ar}$ reaction at $900{ }^{\circ} \mathrm{C}$

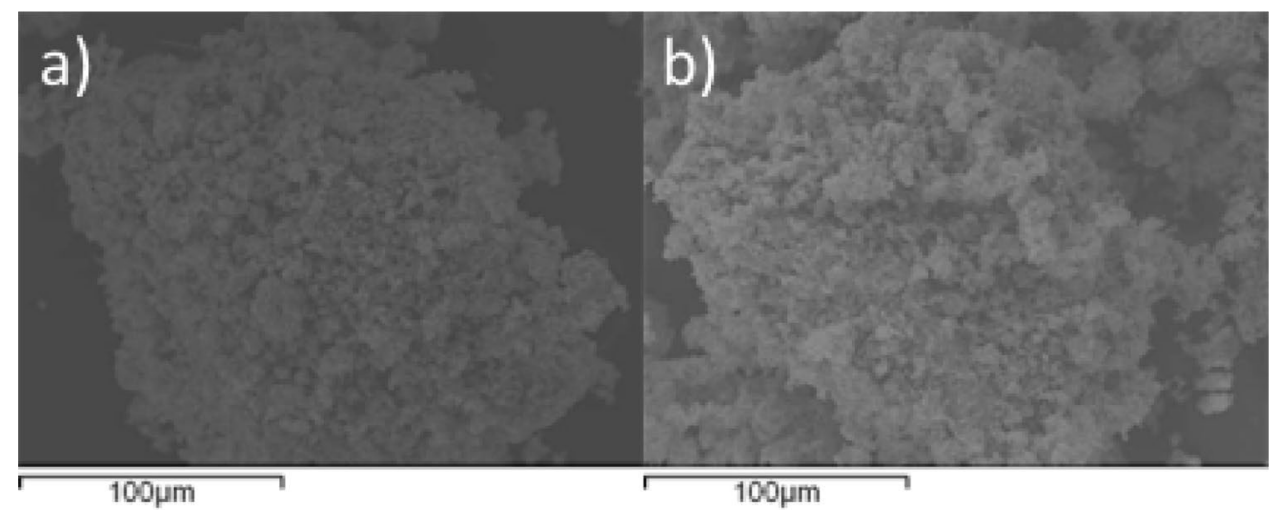




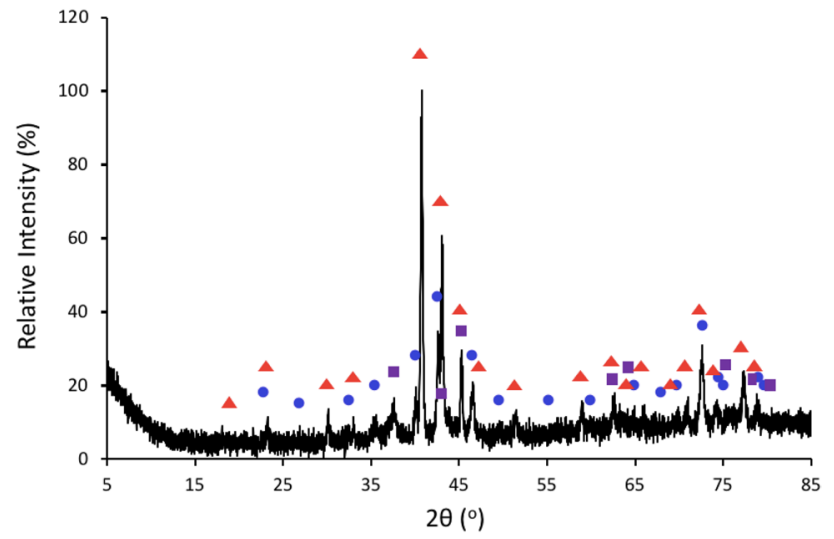

Fig. 3 XRD pattern of prepared $\mathrm{Co}_{2} \mathrm{Mo}_{3} \mathrm{~N}$. (A) $\mathrm{Co}_{2} \mathrm{Mo}_{3} \mathrm{~N}$ (PDF ref.: 01-072-6570), (॰) $\mathrm{Co}_{3} \mathrm{Mo}_{3} \mathrm{~N}$ (PDF ref.: 01-089-7953) and ( $\beta-\mathrm{Mo}_{2} \mathrm{~N}_{0.78}$ (PDF ref.: 03-065-6236)

Table 2 Nitrogen analysis pre- and post-reaction for the prepared "Co ${ }_{2} \mathrm{Mo}_{3} \mathrm{~N}$ " samples

\begin{tabular}{ll}
\hline Material & $\begin{array}{l}\text { Nitrogen } \\
\text { content } \\
(w t \%)\end{array}$ \\
\hline " $\mathrm{Co}_{2} \mathrm{Mo}_{3} \mathrm{~N}$ " & 3.82 \\
" $\mathrm{Co}_{2} \mathrm{Mo}_{3} \mathrm{~N} "$ post $\mathrm{H}_{2} / \mathrm{Ar} 700{ }^{\circ} \mathrm{C}$ & 2.07 \\
" $\mathrm{Co}_{2} \mathrm{Mo}_{3} \mathrm{~N} "$ post $\mathrm{H}_{2} / \mathrm{Ar} 800{ }^{\circ} \mathrm{C}$ & 0.72 \\
" $\mathrm{Co}_{2} \mathrm{Mo}_{3} \mathrm{~N} "$ post $\mathrm{H}_{2} / \mathrm{Ar} 900{ }^{\circ} \mathrm{C}$ & 0.48 \\
\hline
\end{tabular}

was shown to contain the $\mathrm{Co}_{3} \mathrm{Mo}_{3} \mathrm{~N}$ phase, the expected needle morphology for this phase was not observed.

In order to investigate the lattice nitrogen reactivity of the mixed phase $\mathrm{Co}_{2} \mathrm{Mo}_{3} \mathrm{~N}$ and $\mathrm{Co}_{3} \mathrm{Mo}_{3} \mathrm{~N}$, the material was reduced at $700{ }^{\circ} \mathrm{C}, 800{ }^{\circ} \mathrm{C}$ or $900{ }^{\circ} \mathrm{C}$ under $3: 1 \mathrm{H}_{2} / \mathrm{Ar}$ at ambient pressure for $7 \mathrm{~h}$. The conductivity profile data under 3:1 $\mathrm{H}_{2} / \mathrm{Ar}$ at $700{ }^{\circ} \mathrm{C}$ for the mixed $\mathrm{Co}_{2} \mathrm{Mo}_{3} \mathrm{~N}$ and $\mathrm{Co}_{3} \mathrm{Mo}_{3} \mathrm{~N}$ material is provided (Online Resource Fig. S2). A total of $37 \mu \mathrm{mol}$ of ammonia was formed over the $7 \mathrm{~h}$ of reaction. The conductivity profiles for the $800{ }^{\circ} \mathrm{C}$ and $900{ }^{\circ} \mathrm{C}$ reactions (Online Resource Figure S2) show that the rates were non-steady state and the production of ammonia was minimal. The total amount of ammonia formed was $32 \mu \mathrm{mol}$ and $22 \mu \mathrm{mol}$ over the $7 \mathrm{~h}$ at $800{ }^{\circ} \mathrm{C}$ and $900{ }^{\circ} \mathrm{C}$, respectively. These results agree with the limited stability of ammonia under these conditions and therefore, it would be expected that most of the lattice nitrogen would be lost in the final form of $\mathrm{N}_{2}$. The $\mathrm{Co}_{3} \mathrm{Mo}_{3} \mathrm{~N}$ reflections were shown to have shifted to higher $2 \theta$ angles post $700{ }^{\circ} \mathrm{C}$ reaction (Fig. 5a), suggesting that there was a decrease in the lattice nitrogen content of this phase, which is to be expected when it transforms to the $\mathrm{Co}_{6} \mathrm{Mo}_{6} \mathrm{~N}$ phase [13]. Due to the degree of overlap between the reflections of $\mathrm{Co}_{6} \mathrm{Mo}_{6} \mathrm{~N}$ and $\mathrm{Co}_{2} \mathrm{Mo}_{3} \mathrm{~N}$ this is somewhat difficult to observe. However, this was most clearly noticed when comparing the pre- and post-reaction reflection at approximately $35.5^{\circ} 2 \theta$, where there is no overlap of reflections. The shift of $\mathrm{Co}_{3} \mathrm{Mo}_{3} \mathrm{~N}$ reflections to higher
Fig. 4 Representative SEM images of the prepared $\mathrm{Co}_{2} \mathrm{Mo}_{3} \mathrm{~N}$ : a pre-reaction, $\mathbf{b}$ post $\mathrm{H}_{2} / \mathrm{Ar}$ reaction at $700{ }^{\circ} \mathrm{C}$, c post $\mathrm{H}_{2} / \mathrm{Ar}$ reaction at $800{ }^{\circ} \mathrm{C}$ and d post $\mathrm{H}_{2} / \mathrm{Ar}$ reaction at $900{ }^{\circ} \mathrm{C}$
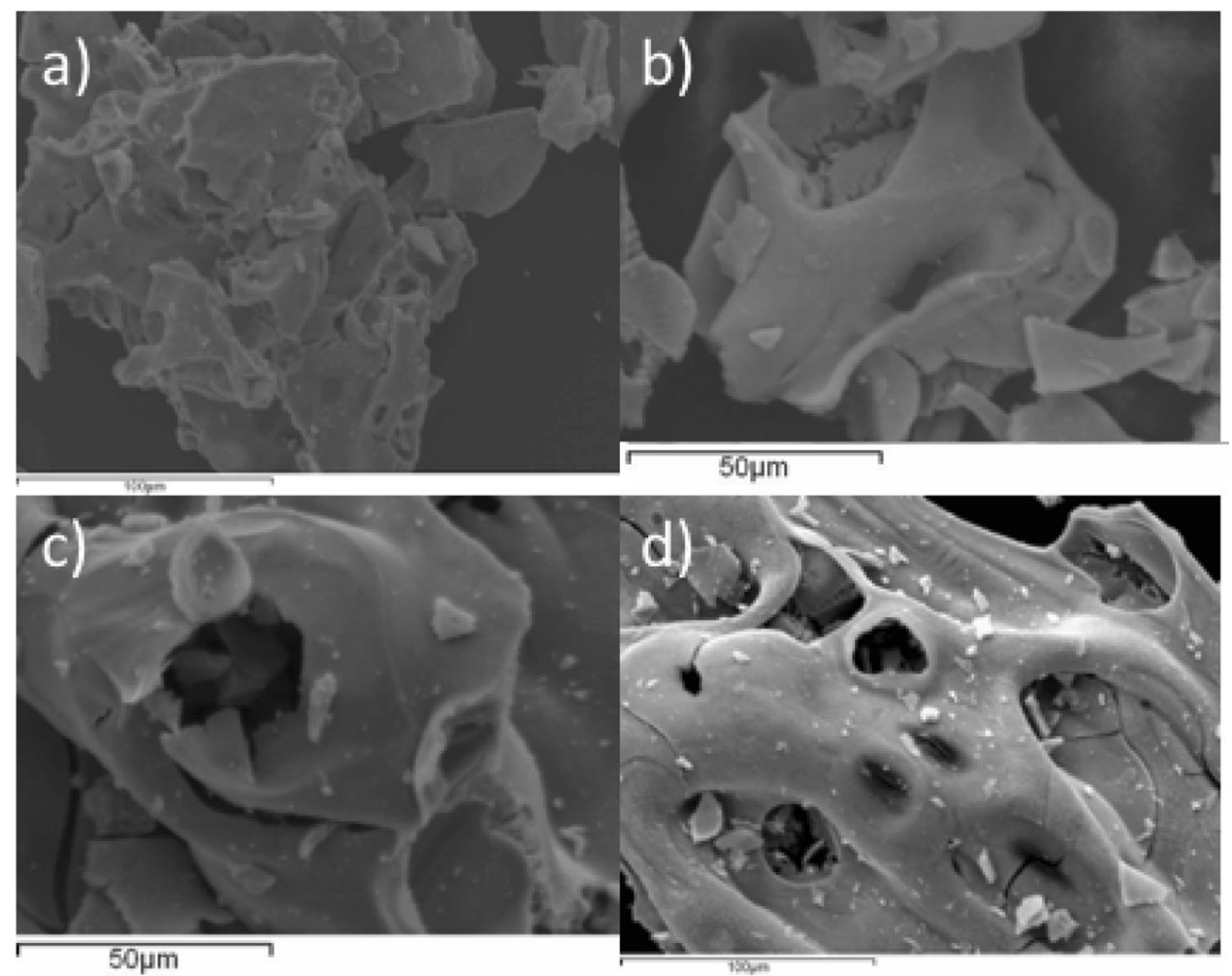


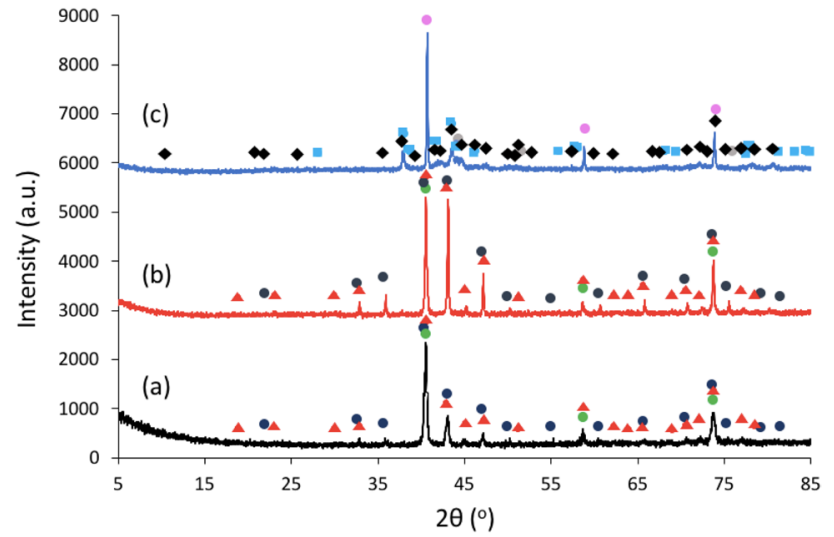

Fig. 5 XRD patterns of mixed $\mathrm{Co}_{2} \mathrm{Mo}_{3} \mathrm{~N}$ and $\mathrm{Co}_{3} \mathrm{Mo}_{3} \mathrm{~N}$ : a postreaction $3: 1 \mathrm{H}_{2} / \mathrm{Ar}$ at $700{ }^{\circ} \mathrm{C}$ b post-reaction $3: 1 \mathrm{H}_{2} / \mathrm{Ar}$ at $800{ }^{\circ} \mathrm{C} \mathrm{c}$ post-reaction 3:1 $\mathrm{H}_{2} / \mathrm{Ar}$ at $900{ }^{\circ} \mathrm{C}(\Delta) \mathrm{Co}_{2} \mathrm{Mo}_{3} \mathrm{~N}$ (PDF ref.: 01-0726570), (๑) $\mathrm{Co}_{6} \mathrm{Mo}_{6} \mathrm{~N}$ (data from [29]), (৫) Mo (PDF ref.: 01-0714645), (॰) $\mathrm{Co}_{0.08} \mathrm{Mo}_{0.92}$ (PDF ref.: 01-071-7326), (॰) $\alpha-\mathrm{Co}$ (PDF ref.: 01-089-4307), ( $\square \mathrm{Co}_{2} \mathrm{~N}$ (PDF ref.: 01-074-8393) and $(\checkmark) \mathrm{Co}_{7} \mathrm{Mo}_{6}$ (PDF ref.: 00-029-0489)

$2 \theta$ values was also observed post $800{ }^{\circ} \mathrm{C}$ reaction (Fig. $5 b$ ). The lattice nitrogen in $\mathrm{Co}_{2} \mathrm{Mo}_{3} \mathrm{~N}$ appears to be unreactive at $700{ }^{\circ} \mathrm{C}$ and $800{ }^{\circ} \mathrm{C}$ under $\mathrm{H}_{2} / \mathrm{Ar}$ as there was no shift in the peak positions for this phase compared to pre-reaction (Fig. 5a, b) as clearly seen by the peak at approximately $45^{\circ} 2 \theta$. These results agree with the previously published work of Adamski et al. who noticed that under pure hydrogen at $700{ }^{\circ} \mathrm{C} \mathrm{Co}_{3} \mathrm{Mo}_{3} \mathrm{~N}$ transitioned to $\mathrm{Co}_{6} \mathrm{Mo}_{6} \mathrm{~N}$, while $\mathrm{Co}_{2} \mathrm{Mo}_{3} \mathrm{~N}$ remained stable [16]. $\beta-\mathrm{Mo}_{2} \mathrm{~N}_{0.78}$ was believed to have been reduced to molybdenum metal during the reaction at both $700{ }^{\circ} \mathrm{C}$ and $800{ }^{\circ} \mathrm{C}$ (Fig. 5a, b). As there are not any unique reflections for Mo, the presence of this phase cannot be completely established. However, it has been previously reported that molybdenum nitride is reduced to Mo under 3:1 $\mathrm{H}_{2} / \mathrm{Ar}$ at $700{ }^{\circ} \mathrm{C}[14]$ and therefore, it would be expected to occur.

The lack of reactivity of the lattice nitrogen in the filled $\beta$-Mn structured $\mathrm{Co}_{2} \mathrm{Mo}_{3} \mathrm{~N}$ under $\mathrm{H}_{2} /$ Ar up to a temperature of $800{ }^{\circ} \mathrm{C}$ has also been observed for the isostructural $\mathrm{Ni}_{2} \mathrm{Mo}_{3} \mathrm{~N}$ and, as discussed above, $\eta$-carbide structured $\mathrm{Fe}_{3} \mathrm{Mo}_{3} \mathrm{~N}[12,14]$. Although $\mathrm{Fe}_{3} \mathrm{Mo}_{3} \mathrm{~N}$ and $\mathrm{Co}_{3} \mathrm{Mo}_{3} \mathrm{~N}$ have the same crystal structure type, the lattice nitrogen reactivity is different between these two nitrides under $\mathrm{H}_{2} / \mathrm{Ar}$ at $700{ }^{\circ} \mathrm{C}$ and $800{ }^{\circ} \mathrm{C}$, suggesting that metal composition is more important than the structure type. However, $\mathrm{Co}_{3} \mathrm{Mo}_{3} \mathrm{~N}$ and $\mathrm{Co}_{2} \mathrm{Mo}_{3} \mathrm{~N}$, have different stabilities suggesting that the phase also has an impact. Therefore, there appears to be a complex relationship between metal composition and phase which controls the lattice nitrogen reactivity of the ternary nitrides. In both the filled $\beta$-Mn structure and $\eta$-carbide structure, the local nitrogen environment is similar with the lattice nitrogen being coordinated to six Mo species in each structure. When $\mathrm{Co}_{3} \mathrm{Mo}_{3} \mathrm{~N}$ transforms into $\mathrm{Co}_{6} \mathrm{Mo}_{6} \mathrm{~N}$, the residual lattice nitrogen relocates from the $16 \mathrm{c}$ site to the $8 \mathrm{a}$ site, an apparently less reactive site from which it is not lost. The XRD pattern of the " $\mathrm{Co}_{2} \mathrm{Mo}_{3} \mathrm{~N}$ " material post $900{ }^{\circ} \mathrm{C}$ reaction shows it has decomposed to $\alpha-\mathrm{Co}, \mathrm{Co}_{0.08} \mathrm{Mo}_{0.92}$ and either a cobalt nitride phase or a cobalt molybdenum alloy (Fig. 5 c). $\mathrm{Fe}_{3} \mathrm{Mo}_{3} \mathrm{~N}$ was shown to have a similar decomposition as $\mathrm{Co}_{2} \mathrm{Mo}_{3} \mathrm{~N}$ and $\mathrm{Co}_{3} \mathrm{Mo}_{3} \mathrm{~N}$ under these conditions. This is again in contrast to the filled $\beta-\mathrm{Mn}$ structured $\mathrm{Ni}_{2} \mathrm{Mo}_{3} \mathrm{~N}$, which was stable at $900{ }^{\circ} \mathrm{C}$ [12]. As expected, the nitrogen analysis showed that the nitrogen content decreased significantly post $\mathrm{H}_{2} / \mathrm{Ar}$ reaction for all three temperatures compared to pre-reaction as seen in Table 2 . As the post $700{ }^{\circ} \mathrm{C}$ reaction material consisted of $\mathrm{Co}_{2} \mathrm{Mo}_{3} \mathrm{~N}, \mathrm{Co}_{6} \mathrm{Mo}_{6} \mathrm{~N}$ and $\mathrm{Mo}$, the stoichiometric percentage in this material is expected to be $1.92 \mathrm{wt} \%$ nitrogen, if it is assumed that the phases have a 1:1:1 ratio. The obtained value of $2.07 \mathrm{wt} \%$ agrees quite well with this value. For the post $800{ }^{\circ} \mathrm{C}$ reaction material, based upon the XRD pattern, it would be expected that the loss of nitrogen from this material is predominantly from the $\mathrm{Co}_{3} \mathrm{Mo}_{3} \mathrm{~N}$ and $\beta-\mathrm{Mo}_{2} \mathrm{~N}_{0.78}$ phases. The significant loss of nitrogen from the post $900{ }^{\circ} \mathrm{C}$ material agrees with the observed decomposition during the reaction. The percentage of the overall nitrogen that was removed from the material and was converted to ammonia was ca. 25\%, 24\% and 13\% for the $700{ }^{\circ} \mathrm{C}, 800{ }^{\circ} \mathrm{C}$ and $900{ }^{\circ} \mathrm{C}$ reactions, respectively. The SEM images in Fig. 4 show that the morphology for all three post $\mathrm{H}_{2} / \mathrm{Ar}$ reaction materials were similar to the pre-reaction material. Therefore, the decomposition of the material during the $900{ }^{\circ} \mathrm{C}$ reaction did not have a major effect on the morphology. However, the material appeared to be more porous following $900{ }^{\circ} \mathrm{C}$ reaction. Other materials have been reported to have a porous nature post-reaction when they decomposed under 3:1 $\mathrm{H}_{2} / \operatorname{Ar}$ [25].

\section{3 $\mathrm{Co}_{3} \mathrm{Mo}_{3} \mathrm{~N}$ Prepared by Nitridation with $\mathrm{N}_{2} / \mathrm{H}_{2}$}

The $\eta$-carbide structured $\mathrm{Co}_{3} \mathrm{Mo}_{3} \mathrm{~N}$ is traditionally prepared in a pure form by temperature programmed ammonolysis of a $\mathrm{CoMoO}_{4}$ precursor $[13,24,26]$. However, the formation of nitrides via temperature programmed ammonolysis has several disadvantages, including reduction in efficiency in the process due to large amounts of heat transfer and problems arising due to using ammonia at a large scale [27]. Therefore, although the bulk lattice nitrogen in $\mathrm{Ni}_{2} \mathrm{Mo}_{3} \mathrm{~N}$ appears to be relatively unreactive, this nitride has an advantage in that it is able to be prepared under $\mathrm{N}_{2} / \mathrm{H}_{2}$ at $700{ }^{\circ} \mathrm{C}$ [18]. $\mathrm{Co}_{3} \mathrm{Mo}_{3} \mathrm{~N}$ appears to be uniquely active with regards to its lattice nitrogen reactivity which could have interesting applications as a nitrogen transfer material. It would therefore be of interest to prepare $\mathrm{Co}_{3} \mathrm{Mo}_{3} \mathrm{~N}$ under $\mathrm{N}_{2} / \mathrm{H}_{2}$. In this work, attempts were made to prepare $\mathrm{Co}_{3} \mathrm{Mo}_{3} \mathrm{~N}$ directly by nitridation of the oxide with $\mathrm{N}_{2} / \mathrm{H}_{2}$ at $700{ }^{\circ} \mathrm{C}, 800{ }^{\circ} \mathrm{C}$ or $900{ }^{\circ} \mathrm{C}$. 
The direct $\mathrm{N}_{2} / \mathrm{H}_{2}$ nitridation process at $700{ }^{\circ} \mathrm{C}$ resulted in a mixed phased material of $\mathrm{Co}_{2} \mathrm{Mo}_{3} \mathrm{~N}$ with minor amounts of $\mathrm{Co}_{3} \mathrm{Mo}_{3} \mathrm{~N}$ and $\beta-\mathrm{Mo}_{2} \mathrm{~N}_{0.78}$ as can be observed in Fig. 6(a). As stoichiometric amounts of cobalt and molybdenum were used in the preparation, it appears that there is unidentified Co present in the material. Cobalt metal may be present but undetected due to peak overlap at $44^{\circ} 2 \theta$, as previously suggested by Adamski et al. [16]. The preparation at $800{ }^{\circ} \mathrm{C}$ results in a mixture of $\mathrm{Co}_{3} \mathrm{Mo}_{3} \mathrm{~N}$ and $\mathrm{Co}_{2} \mathrm{Mo}_{3} \mathrm{~N}$, with $\mathrm{Co}_{3} \mathrm{Mo}_{3} \mathrm{~N}$ being the majority phase (Fig. 6b). A small reflection at $44^{\circ} 2 \theta$ is observed, suggesting that the excess cobalt is present in its elemental form. Preparation at the highest temperature of $900^{\circ} \mathrm{C}$ produces the pure phase highly crystalline $\mathrm{Co}_{3} \mathrm{Mo}_{3} \mathrm{~N}$ (Fig. 6c). Adamski et al. have proposed that the oxide precursor is first transformed to $\mathrm{Co}_{2} \mathrm{Mo}_{3} \mathrm{~N}$ and a molybdenum nitride phase, before forming the $\mathrm{Co}_{3} \mathrm{Mo}_{3} \mathrm{~N}$ phase [28]. Therefore, this may be an explanation for why the pure phased $\mathrm{Co}_{3} \mathrm{Mo}_{3} \mathrm{~N}$ is only formed at high temperatures under $\mathrm{N}_{2} / \mathrm{H}_{2}$. This result shows promise for forming $\mathrm{Co}_{3} \mathrm{Mo}_{3} \mathrm{~N}$ under nitridation conditions. It appears that there

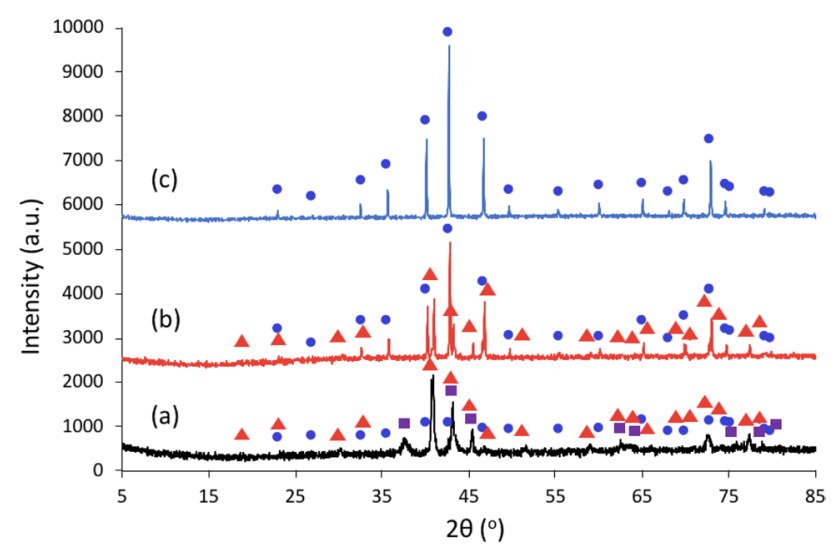

Fig. 6 XRD pattern of prepared $\mathrm{Co}_{3} \mathrm{Mo}_{3} \mathrm{~N}$ : a CoMoN700 b CoMoN800 c Co $\mathrm{Co}_{3} \mathrm{~N} 900$. (๖) $\mathrm{Co}_{3} \mathrm{Mo}_{3} \mathrm{~N}$ (PDF ref.: 01-089-7953),

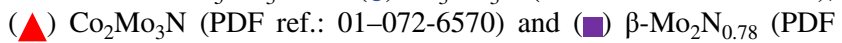
ref.: 03-065-6236) is a significant difference in morphology between the cobalt molybdenum nitrides as observed in Fig. 7. The material prepared at $700{ }^{\circ} \mathrm{C}(\mathrm{CoMoN} 700)$ consists of small solid particles. The morphology of the material prepared at $900{ }^{\circ} \mathrm{C}$ $\left(\mathrm{Co}_{3} \mathrm{Mo}_{3} \mathrm{~N} 900\right)$ was similar to the expected needle structure for $\mathrm{Co}_{3} \mathrm{Mo}_{3} \mathrm{~N}$ that is observed when it is prepared under ammonolysis [4, 29]. The nitrogen analysis (Table 3) mainly agrees with the assignment for the nitrides prepared at the different temperatures. CoMoN700 has the highest nitrogen content. The nitrogen content of the material prepared at $800{ }^{\circ} \mathrm{C}(\mathrm{CoMoN} 800)$ is below that expected for stoichiometric $\mathrm{Co}_{3} \mathrm{Mo}_{3} \mathrm{~N}$ and the material was found from XRD to comprise $\mathrm{Co}_{2} \mathrm{Mo}_{3} \mathrm{~N}, \mathrm{Co}_{3} \mathrm{Mo}_{3} \mathrm{~N}$ and $\mathrm{Co}$. The nitrogen content of $\mathrm{Co}_{3} \mathrm{Mo}_{3} \mathrm{~N} 900$ is in very close agreement with the expected stoichiometric nitrogen weight percentage for $\mathrm{Co}_{3} \mathrm{Mo}_{3} \mathrm{~N}$ (2.93 wt\%), further confirming the successful synthesis of the pure phase $\mathrm{Co}_{3} \mathrm{Mo}_{3} \mathrm{~N}$.

\section{Conclusions}

The bulk lattice nitrogen reactivity of the $\eta$-carbide structured $\mathrm{Fe}_{3} \mathrm{Mo}_{3} \mathrm{~N}$ and $\mathrm{Co}_{3} \mathrm{Mo}_{3} \mathrm{~N}$ and filled $\beta-\mathrm{Mn}$ structured $\mathrm{Co}_{2} \mathrm{Mo}_{3} \mathrm{~N}$ has been investigated by testing the materials under $\mathrm{Ar} / \mathrm{H}_{2}$. The metal composition-activity relationship was examined by comparison of the isostructural $\mathrm{Fe}_{3} \mathrm{Mo}_{3} \mathrm{~N}$ and $\mathrm{Co}_{3} \mathrm{Mo}_{3} \mathrm{~N}$. $\mathrm{Fe}_{3} \mathrm{Mo}_{3} \mathrm{~N}$ was shown to decompose to Mo and an iron nitride phase under $3: 1 \mathrm{H}_{2} / \mathrm{Ar}$ at $900{ }^{\circ} \mathrm{C}$. In the literature, the bulk lattice nitrogen of $\mathrm{Fe}_{3} \mathrm{Mo}_{3} \mathrm{~N}$ has been reported to be unreactive up to a temperature of $800^{\circ} \mathrm{C}[13$,

Table 3 Nitrogen analysis for the prepared $\mathrm{Co}_{3} \mathrm{Mo}_{3} \mathrm{~N}$ samples at different temperatures

\begin{tabular}{ll}
\hline Material & $\begin{array}{l}\text { Nitrogen } \\
\text { content } \\
(\text { wt\%) }\end{array}$ \\
\hline CoMoN700 & 3.99 \\
CoMoN800 & 2.58 \\
$\mathrm{Co}_{3} \mathrm{Mo}_{3} \mathrm{~N} 900$ & 2.88 \\
\hline
\end{tabular}

Fig. 7 Representative SEM images of prepared $\mathrm{Co}_{3} \mathrm{Mo}_{3} \mathrm{~N}$ : a CoMoN700 and $\mathbf{b ~} \mathrm{Co}_{3} \mathrm{Mo}_{3} \mathrm{~N} 900$

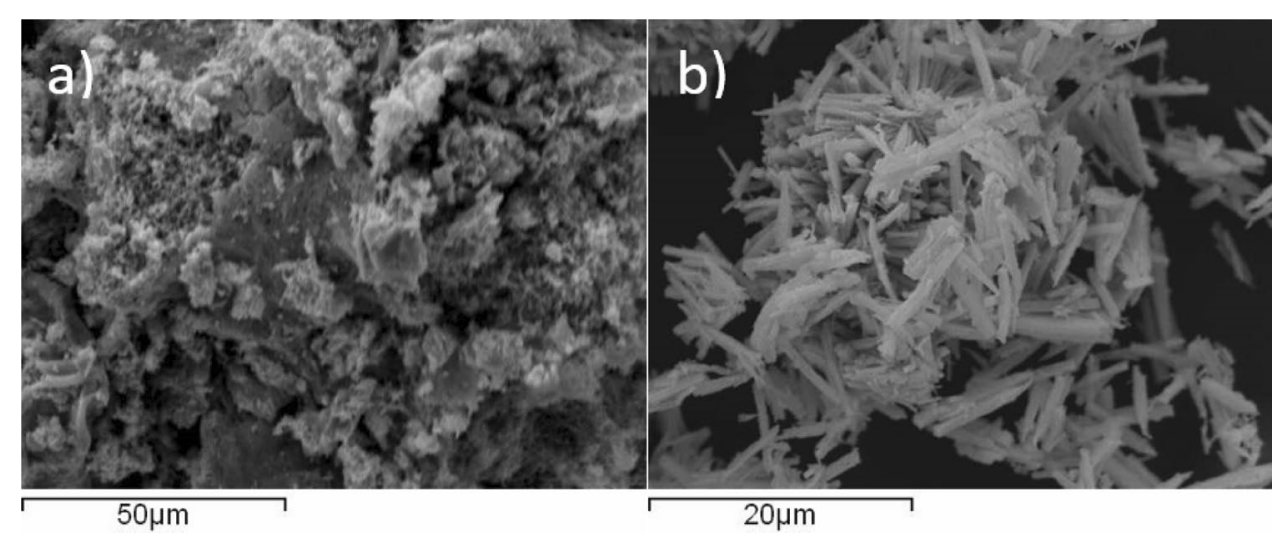


14]. Therefore, it appears that the $\mathrm{Fe}_{3} \mathrm{Mo}_{3} \mathrm{~N}$ phase has a different reactivity to $\mathrm{Co}_{3} \mathrm{Mo}_{3} \mathrm{~N}$, even at high temperatures, possibly suggesting that metal composition is the dominant influence on the bulk lattice nitrogen reactivity. Additionally, with this in mind, an investigation of the filled $\beta-\mathrm{Mn}$ structured $\mathrm{Co}_{2} \mathrm{Mo}_{3} \mathrm{~N}$ and the $\eta$-carbide structured $\mathrm{Co}_{3} \mathrm{Mo}_{3} \mathrm{~N}$ has also been performed to provide an insight into a possible structure-activity relationship. The filled $\beta$-Mn structured $\mathrm{Co}_{2} \mathrm{Mo}_{3} \mathrm{~N}$ could not be synthesised in the pure form, with instead the material being a mixture of $\mathrm{Co}_{2} \mathrm{Mo}_{3} \mathrm{~N}$ and $\mathrm{Co}_{3} \mathrm{Mo}_{3} \mathrm{~N}$. The mixed phase $\mathrm{Co}_{2} \mathrm{Mo}_{3} \mathrm{~N}$ and $\mathrm{Co}_{3} \mathrm{Mo}_{3} \mathrm{~N}$ were examined for their lattice nitrogen reactivities between $700{ }^{\circ} \mathrm{C}$ and $900{ }^{\circ} \mathrm{C}$ under $3: 1 \mathrm{H}_{2} / \mathrm{Ar}$. At $700{ }^{\circ} \mathrm{C}$ and $800{ }^{\circ} \mathrm{C}$, the filled $\beta$-Mn structured $\mathrm{Co}_{2} \mathrm{Mo}_{3} \mathrm{~N}$ was shown to be stable and $\eta$-carbide structured $\mathrm{Co}_{3} \mathrm{Mo}_{3} \mathrm{~N}$ was observed to be more reactive by losing the majority of its lattice nitrogen. When reacted at $900{ }^{\circ} \mathrm{C}$, the material decomposed to its metal constituents and the majority of the lattice nitrogen was removed, as was observed for $\mathrm{Fe}_{3} \mathrm{Mo}_{3} \mathrm{~N}$. It has previously been observed that the filled $\beta$-Mn structured $\mathrm{Ni}_{2} \mathrm{Mo}_{3} \mathrm{~N}$ was stable at this temperature [12]. Overall, the lattice nitrogen reactivity of the ternary nitrides has been found to be complex. Additionally, pure phase $\eta$-carbide structured $\mathrm{Co}_{3} \mathrm{Mo}_{3} \mathrm{~N}$ with needle morphology was synthesised under 3:1 $\mathrm{H}_{2} / \mathrm{N}_{2}$ at $900{ }^{\circ} \mathrm{C}$.

Supplementary Information The online version contains supplementary material available at https://doi.org/10.1007/s11244-021-01432-1.

Acknowledgements We wish to acknowledge the UK Engineering and Physical Science Research Council for funding (EPSRC Grant Number EP/N509668/1). We are also very grateful to both Mr Gangi Reddy Ubbara and Mr Jim Gallagher of School of Chemistry, University of Glasgow for their very kind assistance with combustion analyses and SEM imaging respectively. In contributing to this special memorial issue of Topics in Catalysis, JSJH would like to acknowledge the many interesting scientific discussions which he was fortunate to have over the years with Mike Spencer, who is greatly missed.

Funding This research was supported by UK Engineering and Physical Science Research Council (EPSRC).

Data Availability The data generated in this work are available on reasonable request to the corresponding authors.

Open Access This article is licensed under a Creative Commons Attribution 4.0 International License, which permits use, sharing, adaptation, distribution and reproduction in any medium or format, as long as you give appropriate credit to the original author(s) and the source, provide a link to the Creative Commons licence, and indicate if changes were made. The images or other third party material in this article are included in the article's Creative Commons licence, unless indicated otherwise in a credit line to the material. If material is not included in the article's Creative Commons licence and your intended use is not permitted by statutory regulation or exceeds the permitted use, you will need to obtain permission directly from the copyright holder. To view a copy of this licence, visit http://creativecommons.org/licenses/by/4.0/.

\section{References}

1. Pfromm PH (2017) Towards sustainable agriculture: fossil-free ammonia. J Renew Sustain Energy 9:034702

2. Kojima R, Aika K (2001) Cobalt molybdenum bimetallic nitride catalysts for ammonia synthesis-Part 1. preparation and characterisation. Appl Catal A Gen 215:149-160

3. Jacobsen CJ, Dahl S, Clausen BS, Logadottir A, Norskov JK (2001) Catalyst design by interpolation in the periodic table: bimetallic ammonia synthesis catalysts. J Am Chem Soc 123:8404-8405

4. AlShibane I, Daisley A, Hargreaves JSJ, Hector AL, Laassiri S, Rico JL, Smith RI (2017) The role of composition for cobalt molybdenum carbide in ammonia synthesis. ACS Sustainable Chem Eng 5:9214-9222

5. Hunter SM, Gregory DH, Hargreaves JSJ, Richard M, Duprez $\mathrm{D}$, Bion N (2013) A study of ${ }^{15} \mathrm{~N} /{ }^{14} \mathrm{~N}$ isotopic exchange over cobalt molybdenum nitrides. ACS Catal 3:1719-1725

6. Zeinalipour-Yazdi CD, Hargreaves JSJ, Catlow CRA (2018) Low-T mechanisms of ammonia synthesis on $\mathrm{Co}_{3} \mathrm{Mo}_{3} \mathrm{~N}$. J Phys Chem C 122:6078-6082

7. Zeinalipour-Yazdi CD, Hargreaves JSJ, Catlow CRA (2015) Nitrogen activation in a Mars-van Krevelen mechanism for ammonia synthesis on $\mathrm{Co}_{3} \mathrm{Mo}_{3} \mathrm{~N}$. J Phys Chem C 119:28368-28376

8. Spencer MS (1992) On the rate-determining step and the role of potassium in the catalytic synthesis of ammonia. Catal Lett 13:45-54

9. Hunter SM, Mckay D, Smith RI, Hargreaves JSJ, Gregory DH (2010) Topotactic nitrogen transfer: structural transformation in cobalt molybdenum nitrides. Chem Mater 22:2898-2907

10. McKay D, Gregory DH, Hargreaves JSJ, Hunter SM, Sun X-L (2007) Towards nitrogen transfer catalysis: reactive lattice nitrogen in cobalt molybdenum nitride. Chem Commun 29:3051-3053

11. Gregory DH, Hargreaves JSJ, Hunter SM (2011) On the regeneration of $\mathrm{Co}_{3} \mathrm{Mo}_{3} \mathrm{~N}$ from $\mathrm{Co}_{6} \mathrm{Mo}_{6} \mathrm{~N}$ with $\mathrm{N}_{2}$. Catal Lett 141:22-26

12. Daisley A (2020) The role of composition on the ammonia synthesis activity of nitrides, carbonitrides, carbides and osmium based compounds. PhD Thesis, University of Glasgow

13. McKay D, Hargreaves JSJ, Rico JL, Rivera JL, Sun X-L (2008) The influence of phase and morphology of molybdenum nitrides on ammonia synthesis activity and reduction characteristics. J Solid State Chem 181:325-333

14. Hunter S M (2012) Molybdenum nitrides: Structural and reactivity studies. PhD Thesis, University of Glasgow

15. Conway JO, Prior TJ (2019) Interstitial nitrides revisited-a simple synthesis of $\mathrm{M}_{\mathrm{x}} \mathrm{Mo}_{3} \mathrm{~N}(\mathrm{M}=\mathrm{Fe} \mathrm{Co}, \mathrm{Ni})$. J Alloys Compd 774:69-74

16. Adamski P, Moszynski D, Nadziejko M, Komorowska A, Sarnecki A, Albrecht A (2019) Thermal stability of catalyst for ammonia synthesis based on cobalt molybdenum nitrides. Chem Pap 73:851-859

17. Bem DS, Gibson CP, zur Loye HC (1993) Synthesis of intermetallic nitrides by solid-state precursor reduction. Chem Mater 5:397-399

18. Bion N, Can F, Cook J, Hargreaves JSJ, Hector AL, Levason W, McFarlane AR, Richard M, Sardar K (2015) The role of preparation route upon the ambient pressure ammonia synthesis activity of $\mathrm{Ni}_{2} \mathrm{Mo}_{3} \mathrm{~N}$. Appl Catal A Gen 504:44-50

19. Panda RN, Gajbhiye NS (1997) Electronic and magnetic properties of $\mathrm{Fe}_{3} \mathrm{Mo}_{3} \mathrm{~N}$. J Alloys Compd 256:102-107

20. Jacobsen CJ (2000) Novel class of ammonia synthesis catalysts. Chem Comm 12:1057-1058 
21. Choi J-G, Curl RL, Thompson LT (1994) Molybdenum nitride catalysts 1 . Influence of the synthesis factors on structural properties. J Catal 146:218-227

22. Volpe L, Oyama ST, Boudart M (1983) Synthesis, surface reactivity, and catalytic activity of high specific surface area molybdenum nitride powders. In: Poncelet G, Grange P, Jacobs PA (eds) Preparation of catalysts III. Elsevier, Amsterdam

23. Marnellos G, Stoukides M (1998) Ammonia synthesis at atmospheric pressure. Science 282:98-100

24. Hargreaves JSJ, McKay D (2009) A comparison of the reactivity of lattice nitrogen in $\mathrm{Co}_{3} \mathrm{Mo}_{3} \mathrm{~N}$ and $\mathrm{Ni}_{2} \mathrm{Mo}_{3} \mathrm{~N}$ catalysts. $\mathrm{J}$ Mol Catal A Chem 305:125-129

25. Alexander A-M, Hargreaves JSJ (2012) The reduction of various nitrides under hydrogen: $\mathrm{Ni}_{3} \mathrm{~N}, \mathrm{Cu}_{3} \mathrm{~N}, \mathrm{Zn}_{3} \mathrm{~N}_{2}$ and $\mathrm{Ta}_{3} \mathrm{~N}_{5}$. Top Catal 55:1046-1053

26. Kojima R, Aika K-I (2000) Cobalt molybdenum bimetallic nitride catalysts for ammonia synthesis. Chem Lett 29:514-515
27. Wise RS, Markel EJ (1994) Synthesis of high surface area molybdenum nitride in mixtures of nitrogen and hydrogen. J Catal 145:344-355

28. Adamski P, Moszynski D, Komorowska A, Nadziejko M, Sarnecki A, Albrecht A (2018) Ammonolysis of cobalt molybdenum oxides-in situ XRD study. Inorg Chem 57:9844-9850

29. Alshibane I (2018) Phase transformations of ternary carbides, nitrides and carbonitrides. PhD Thesis, University of Glasgow

Publisher's Note Springer Nature remains neutral with regard to jurisdictional claims in published maps and institutional affiliations. 